\title{
COMPARATIVE TOLERANCE AND PHYTOSTABILIZATION POTENTIAL OF Conocarpus erectus AND Eucalyptus camaldulensis GROWN IN CADMIUM CONTAMINATED SOIL
}

\author{
Farah Ashraf ${ }^{1}$, Ghulam Abbas ${ }^{1, *}$, Behzad Murtaza1, Muhammad Amjad ${ }^{1}$, Muhammad Imran', \\ Muhammad Asif Naeem", Muhammad Saqib², Nabeel Khan Niazi ${ }^{2,3}$, Ali Zakir ${ }^{1}$, Munawar \\ Hussain ${ }^{2}$ and Rahat Shabir ${ }^{1}$
}

\author{
${ }^{1}$ Department of Environmental Sciences, COMSATS University Islamabad, Vehari Campus, Pakistan; ${ }^{2}$ Institute of \\ Soil and Environmental Sciences, University of Agriculture, Faisalabad, Pakistan; ${ }^{3}$ MARUM and Department of \\ Geosciences, University of Bremen, Bremen D-28359, Germany \\ *Corresponding author's e-mail: g.a92pk@gmail.com
}

\begin{abstract}
Phytoremediation is the most promising approach for the remediation of $\mathrm{Cd}$ contaminated soils. In the present study, $\mathrm{Cd}$ tolerance and phytoremediation potential of Conocarpus erectus and Eucalyptus camaldulensis, was evaluated in a pot experiment for a growth period of 6 months. Two-month-old plants of uniform size were transplanted in Cd-contaminated soil $\left(0,5,10\right.$ and $\left.15 \mathrm{mg} \mathrm{kg}^{-1}\right)$, and their growth attributes, chlorophyll contents, root and shoot $\mathrm{Cd}$ concentration, bioconcentration factor (BCF) and translocation factor (TF) were determined. With increasing soil Cd levels, shoot and root biomass, leaf water and chlorophyll contents (chl a, chl b and total chl) of E. camaldulensis were decreased more than C. erectus. Shoot and root $\mathrm{Cd}$ concentrations as well as $\mathrm{Cd}$ uptake were more in $C$. erectus than $E$. camaldulensis. The TF was less than one for both plant species, while $\mathrm{BCF}$ was more than one. It is concluded that due to relatively higher Cd tolerance and greater capacity to retain higher concentration of $\mathrm{Cd}$ in roots, C. erectus is a better species than E. camaldulensis for phytostabilization of $\mathrm{Cd}$ contaminated soils.
\end{abstract}

Keywords: Tree species, cadmium, phytostabilization, chlorophyll contents.

\section{INTRODUCTION}

Soil contamination with heavy metals is increasing worldwide due to various anthropogenic activities such as mining, pesticide manufacturing, industrial effluents and waste discharges (Ghosh et al., 2016; Shabir et al., 2017). Amongst various heavy metals, cadmium $(\mathrm{Cd})$ is regarded as the fourth most toxic heavy metal to the higher plants (Ghosh and Singh, 2005) due to its higher mobility in soil-plant system (KabataPendias and Dudka, 1990; Qayyum et al., 2017).

The normal concentration of $\mathrm{Cd}$ in uncontaminated soil ranges between 0.1 and $0.5 \mathrm{mg} \mathrm{kg}^{-1}$ (Liu et al., 2012), but it can reach up to $3 \mathrm{mg} \mathrm{kg}^{-1}$ depending on the soil parent materials (Nazar et al., 2012). In the case of high $\mathrm{Cd}$ contamination, concentration up to $8 \mathrm{mg} \mathrm{Cd} \mathrm{kg}^{-1}$ soil had been reported for some soils whereas soluble levels as low as 0.001 $\mathrm{mg} \mathrm{kg}{ }^{-1}$ have been found toxic for many plants (KabataPendias and Dudka, 1990). Being a very mobile element, Cd is easily taken up by plants roots (Wang et al., 2016).

The important factors affecting $\mathrm{Cd}$ availability in soil include; organic matter, soil $\mathrm{pH}$, hydrous metal oxide content, clay content and type, other metal cations, presence of organic and inorganic ligands and soil salinity (He et al., 2015; Shabir et al., 2017). Plants growing on Cd contaminated soils show limited growth and biomass production due to disturbance in nutrient uptake and water balance, stomatal closure, changes in antioxidant and carbohydrate metabolism, and injuries to the photosynthetic apparatus (Gomes et al., 2012).

The remediation of $\mathrm{Cd}$ contaminated soils can be done by various physical, chemical and biological approaches (Pietrini et al., 2015; Agnello et al., 2016; Sarwar et al., 2017). Currently available physical and chemical approaches have many limitations including high cost, rigorous labor, small scale application and disturbance to soil structure (Ali et al., 2013). In contrast, phytoremediation is the cost-effective, solar-driven, efficient, eco-friendly and socially accepted approach for remediation of polluted soils (Bhargava et al., 2012; Ali et al., 2013; He et al., 2015; Sarwar et al., 2017). Phytoremediation is further divided into different categories such as phytoextraction, phytovolatilization, phytostimulation, rhizofilteration, phytotransformation, and phytostabilization (Sarwar et al., 2017). In phytostabilization, the major proportion of metals is accumulated in plant roots, and its further spreading to the surrounding environment is greatly reduced (Pilon-Smits, 2005; Hussain et al., 2017). The mechanisms contributing to immobilization and sequestration of $\mathrm{Cd}$ in roots include the chelation of $\mathrm{Cd}$ by thiol-containing peptides such as metallothioneins and phytochelatins, $\mathrm{Cd}$ 
compartmentalization in the vacuoles of root cells, and adsorption to the root cell walls (Nocito et al., 2011; Fine et al., 2013).

Metal uptake and biomass production potential of plants are the main considerations for selecting the plants for phytoremediation purpose (Manousaki et al., 2009; Niazi et al., 2017). Plant species having high metal tolerance and accumulation potential along with high biomass productivity are excellent choice for restoration of contaminated sites (Pulford and Watson, 2003; Pietrini et al., 2015; Shabir et al., 2017). The use of different tree species for phytoremediation of metal polluted soils is regarded as the most promising approach (Pulford and Watson, 2003; Fine et al., 2013). Even though trees accumulate comparatively small quantities of metals, yet they are the most economical type of plants having deep root system and high biomass productivity with very low input. Moreover, they provide economic return from contaminated barren lands, and can remediate marginal quality soils having low fertility and poor structure (Pulford and Watson, 2003; Qados et al., 2015; Pietrini et al., 2015; Abbas et al., 2016).

Phytoremediation potential of different species of Eucalyptus (Fine et al., 2013; Pietrini et al., 2015) and Conocarpus (Qados et al., 2015) has been investigated for $\mathrm{Cd}$ in soils under different climates. However, to our knowledge, no study has explored the comparative $\mathrm{Cd}$ phytoremediation potential of Eucalyptus camaldulensis and Conocarpus erectus under similar soil and climatic conditions. Both of these tree species are commonly grown in Pakistan due to their fast growth, high biomass production, tolerance to harsh growth conditions, and adaptability to local climate. The present study has been planned to investigate the comparative Cd tolerance potential of both these species in terms of growth, leaf water contents and pigment contents. Moreover, their comparative phytoremediation potential in a $\mathrm{Cd}$ contaminated sandy loam soil has been explored.

\section{MATERIALS AND METHODS}

Site and weather conditions: A pot experiment was conducted in a wire house at COMSATS University Islamabad (CUI), Vehari Campus - Pakistan (latitude $30.02^{\circ}$ $\mathrm{N}$, longitude $72.21^{\circ} \mathrm{E}$ ) during 2015-2016. The Vehari district consists of plain areas located at an altitude of $446 \mathrm{ft}(135 \mathrm{~m})$ with very hot summer (April-August, up to $50{ }^{\circ} \mathrm{C}$ temperature) and a very cold winter (November-January, up to $4{ }^{\circ} \mathrm{C}$ temperature). Average annual rain fall in Vehari is about $127 \mathrm{~mm}$ which pours mainly during monsoon season (July-August). Land is semi-arid and dusty due to very little rain around the year.

Growth conditions: The average weather conditions during the experiment were as: sunshine; 8 hours and 24 minutes, minimum temperature; $12.5^{\circ} \mathrm{C}$, maximum temperature; 28.3
${ }^{\circ} \mathrm{C}$, minimum relative humidity; $46 \%$ and maximum relative humidity; $78 \%$.

Soil and water analyses: Surface soil (0-15 cm depth) was collected from the experimental field of CUI-Vehari Campus. The soil was air-dried, ground and passed through a $2-\mathrm{mm}$ sieve for the removal of plant parts, debris and gravels. The soil was analyzed for various physico-chemical properties as shown in Table 1. Hydrometer method (Bouyoucos, 1962) was followed for soil textural class determination using USDA textural triangle. Soil saturated paste was used for $\mathrm{pH}_{\mathrm{s}}$ measurement and soil saturation extract was used for electrical conductivity (EC) measurement. Soil organic matter (OM) content was determined by the method of WalkleyBlack (Jackson, 1962), and lime $\left(\mathrm{CaCO}_{3}\right)$ contents were determined as described by Manousaki and Kalogerakis (2009). Soluble cations and anions were measured by titration (Richards, 1954) and used for residual sodium carbonate (RSC) and sodium adsorption ratio (SAR) calculations. Canal water (Table 1) was used to irrigate the plants.

Table1. The characteristics of soil and water used in the experiment

\begin{tabular}{ccc}
\hline Characteristic & Unit & Value \\
\hline Soil analysis & & \\
Texture & - & Sandy loam \\
OM & $\%$ & $0.36 \pm 0.08$ \\
Available P & $\mathrm{mg} \mathrm{kg}^{-1}$ & $5.5 \pm 0.52$ \\
pHs & - & $8.11 \pm 1.00$ \\
EC & $\mathrm{dS} \mathrm{m}^{-1}$ & $1.30 \pm 0.06$ \\
TSS & $\mathrm{mmol}_{\mathrm{c}} \mathrm{L}^{-1}$ & $13.0 \pm 1.50$ \\
SAR & $\left(\mathrm{mmol} \mathrm{L}^{-1}\right)^{1 / 2}$ & $4.10 \pm 0.45$ \\
Cd & $\mathrm{mg} \mathrm{kg}^{-1}$ & $0.30 \pm 0.07$ \\
Water analysis & & \\
EC & $\mathrm{dS} \mathrm{m}^{-1}$ & $0.21 \pm 0.02$ \\
TSS & $\mathrm{mmol}_{\mathrm{c}} \mathrm{L}^{-1}$ & $2.10 \pm 0.41$ \\
SAR & $\left(\mathrm{mmol} \mathrm{L}^{-1}\right)^{1 / 2}$ & $1.91 \pm 0.33$ \\
RSC & $\mathrm{mmol} \mathrm{L}^{-1}$ & Nil \\
Cd & $\mathrm{mg} \mathrm{kg}^{-1}$ & Not detected \\
\hline
\end{tabular}

Where $\mathrm{OM}=$ organic matter, $\mathrm{pHs}=\mathrm{pH}$ of saturated soil paste, $\mathrm{EC}=$ electrical conductivity, $\mathrm{TSS}=$ total soluble salts, $\mathrm{SAR}=$ sodium adsorption ratio, $\mathrm{RSC}=$ residual sodium carbonate, and $\mathrm{Cd}=$ cadmium concentration.

Experimental set-up and treatments: Soil was spiked with different $\mathrm{Cd}$ concentrations $\left(0,5,10\right.$ and $15 \mathrm{mg} \mathrm{kg}^{-1}$ soil) using $\mathrm{CdCl}_{2}$ salt and was equilibrated at $70 \%$ water holding capacity for four weeks as described by Niazi et al. (2011). Soil water holding capacity was measured using SM150T soil moisture sensor. The available $\mathrm{Cd}$ concentrations after spiking were determined by DTPA-extractable method (Lindsay and Norvell, 1978). These concentrations were 4.20, 8.50 and 13.41 for 5,10 and $15 \mathrm{mg} \mathrm{kg} \mathrm{kg}^{-1}$ applied soil Cd levels, respectively. The soil was filled in pots at the rate of seven $\mathrm{kg}$ per pot. All the pots were arranged in a completely randomized design and each treatment was replicated three 
times. Two-month-old uniform plants of E. camaldulensis and $C$. erectus were transferred to pots keeping one plant of each species in each pot. All the cultural practices such as irrigation, weeding and hoeing were carried out uniformly in all the pots.

Plant harvesting and growth measurements: The plants were harvested after six months of growth in pots. After harvesting of shoots, the roots were carefully collected from each pot. Adhering soil was removed by thorough washing of roots in tap water. The roots were rinsed in $0.01 \mathrm{M} \mathrm{H}_{2} \mathrm{SO}_{4}$ for 30 seconds, and thereafter washed with distilled water to remove surface adsorbed $\mathrm{Cd}$. Plant height and root length were measured using a scale. Shoot and root samples were air dried, and then oven dried at $65{ }^{\circ} \mathrm{C}$ for 48 hours to record their dry weights. Plant height stress tolerance index (PHSTI), root length stress tolerance index (RLSTI), shoot dry matter stress tolerance index (SDMSTI) and root dry matter stress tolerance index (RDMSTI), were calculated using the following equations as described by Kausar et al. (2012).

PHSTI = plant height of stressed plant $/$ plant height of

control plant $\times 100$

RLSTI= root length of stressed plant/ root length of control plant $\times 100$

SDMSTI $=$ shoot dry matter of stressed plant $/$ shoot dry matter of control plant $\times 100$

RDMSTI $=$ root dry matter of stressed plant / root dry matter of control plant $\times 100$

Chlorophyll and leaf water contents: At harvest, fully mature leaf samples $(0.4 \mathrm{~g})$ were randomly collected from upper part of each plant. Following washing in distilled water, the samples were homogenized in $80 \%$ acetone solution using a porcelain mortar and pestle. The extract was centrifuged at $3000 \mathrm{rpm}$ for 10 minutes, and the absorbance of the extract was noted at 663.2, 646.8 and $470 \mathrm{~nm}$ against an extraction buffer control using a UV-Vis spectrophotometer (UVvisible Spectrometer Lambda 25/35/45, PerkinElmer, Inc. USA).

The pigment contents (chlorophyll a, b and total chlorophylls $\mathrm{a}+\mathrm{b}$ ) were calculated using the equations described by Lichtenthaler (1987).

Chlorophyll-a $=12.25 *$ Abs $663.2-2.798 *$ Abs 646.8

Chlorophyll-b $=21.5^{*}$ Abs 646.8 $-5.1 *$ Abs 663.2

Total chlorophyll $=7.15^{*}$ Abs $663.2+18.71 *$ Abs 646.8

Fresh weight (FW) and dry weight (DW) of leaves were used for calculating leaf water contents (WC) as given below.

$\mathrm{WC}=(\mathrm{FW}-\mathrm{DW}) /(\mathrm{FW}) \times 100$

Wet digestion and cadmium determination: Root and shoot samples were ground using a grinding machine. One-gram ground plant sample was taken in conical flask and digested following the protocols as described by AOAC (1990) using $\mathrm{HNO}_{3}$ and $\mathrm{HClO}_{4}$ in 2:1 ratio. Cadmium concentrations in aliquot were determined by atomic absorption spectrophotometer, Perkin Elmer Model: PinAAcle 900F, Inc. USA). Internal standards, reagent blanks and certified reference materials were used for quality assurance and accuracy in Cd determination. Shoot and root Cd uptake was calculated by multiplying the $\mathrm{Cd}$ concentration of each part with dry weight of that part.

Bioconcentration and translocation factors: Bioconcentration factor (BCF) and translocation factor (TF) were calculated as described by Marrugo-Negrete et al. (2015). The BCF was calculated as the ratio of $\mathrm{Cd}$ concentrations in the roots to that in soil. The TF was expressed as the ratio $\mathrm{Cd}$ concentration in the shoots to that in roots.

Statistical analysis: A completely randomized design (CRD) with three replicates was used for the analysis of data. Twoway analysis of variance (ANOVA) of the data was carried out (Steel et al., 1997) using statistical software package "Statistix 8.1". Comparison of treatments was done by standard error of means and least significant difference (LSD) test at $5 \%$ significance level.

\section{RESULTS}

Cadmium tolerance: Cadmium tolerance of both tree species was expressed in terms of tolerance indices for various growth attributes. Plant height stress tolerance index (PHSTI) of both tree species was decreased with increasing soil $\mathrm{Cd}$ levels (Fig. 1a). The comparison of both species showed that PHSTI of $C$. erectus was decreased from $98 \%$ to $83 \%$ as the soil $\mathrm{Cd}$ concentration was increased from 5 to $15 \mathrm{mg} \mathrm{kg}^{-1}$ soil. The respective decrease in PHSTI of E. camaldulensis was from $96 \%$ to $73 \%$ when soil Cd concentration was increased from 5 to $15 \mathrm{mg} \mathrm{kg}^{-1}$ soil. Root length stress tolerance index (RLSTI) was also gradually decreased in both species with increasing soil Cd contamination (Fig. 1b). It decreased from $96 \%$ to $82 \%$ in C. erectus, and from $94 \%$ to $71 \%$ in $E$. camaldulensis, respectively as the soil $\mathrm{Cd}$ concentration was increased from 5 to $15 \mathrm{mg} \mathrm{kg}^{-1}$ soil. A gradual decrease was observed in shoot dry matter stress tolerance index (SDMSTI) of both species with increasing soil Cd levels (Fig. 1c). It decreased from $95 \%$ to $82 \%$ in C. erectus, and from $93 \%$ to $73 \%$ in E. camaldulensis when soil Cd level was increased from the lower to higher level. Likewise, root dry matter stress tolerance index (RDMSTI) decreased from $96 \%$ to $82 \%$, and from $95 \%$ to $72 \%$ in C. erectus and E. camaldulensis, respectively, with increasing soil Cd levels from 5 to $15 \mathrm{mg}$ $\mathrm{kg}^{-1}$ soil (Fig. 1d).

Leaf water and chlorophyll contents: Leaf water and chlorophyll contents of $C$. erectus were not much affected at various soil $\mathrm{Cd}$ levels except for $15 \mathrm{mg} \mathrm{kg}^{-1}$ soil $\mathrm{Cd}$ level. However, in case of E. camaldulensis, both 10 and $15 \mathrm{mg} \mathrm{kg}$ ${ }^{1}$ soil $\mathrm{Cd}$ levels caused significant reduction in these attributes as compared to the control treatment. Leaf water contents were decreased by $17 \%$ and $22 \%$ in $C$. erectus and $E$. camaldulensis, respectively at $15 \mathrm{mg} \mathrm{kg}^{-1}$ soil $\mathrm{Cd}$ level (Fig. 2a). Chlorophyll contents (chl a, chl b and total chl) were 

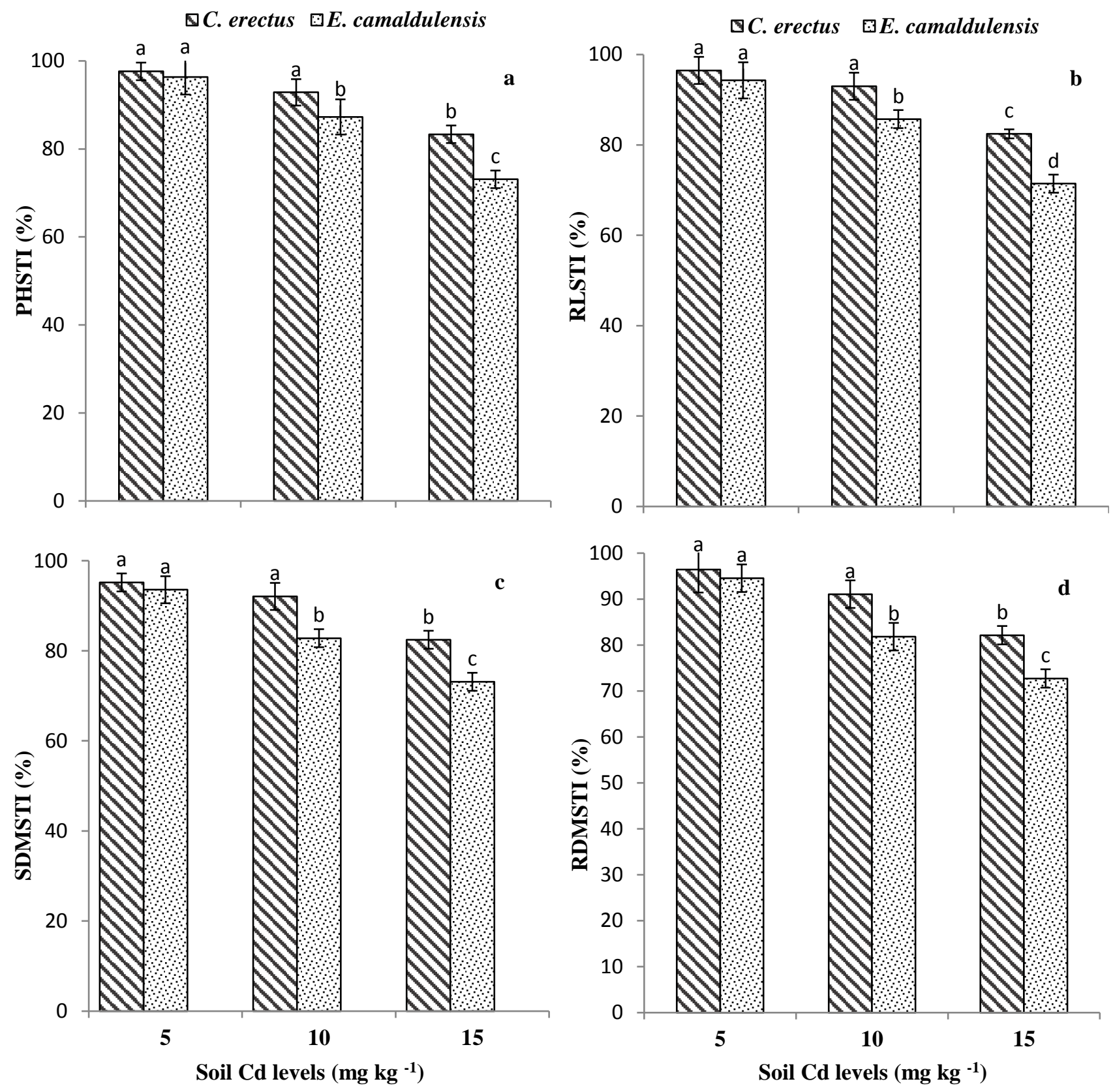

Figure 1. Effects of different soil $\mathrm{Cd}$ levels $\left(\mathrm{mg} \mathrm{kg}^{-1}\right)$ on Cd tolerance attributes of C. erectus and E. camaldulensis. Values are the mean \pm standard error of three replicates.

decreased by $16 \%, 15 \%$ and $16 \%$ in C. erectus and by $27 \%$, $26 \%$ and $27 \%$ in E. camaldulensis, respectively at the highest soil Cd level (15 mg kg-1 soil) as compared to respective control treatment (Fig. 2b, c, d).

Shoot and root Cd concentration and uptake: Data regarding $\mathrm{Cd}$ concentration showed that shoot and root $\mathrm{Cd}$ concentrations in both species were increased with increasing soil Cd levels (Fig. 3a, b). Shoot Cd concentrations were increased from 4.20 to 9.70 in $C$. erectus and from 3.30 to $8.50 \mathrm{mg} \mathrm{kg}^{-1}$ in E. camaldulensis, as the soil Cd concentration was increased from 5 to $15 \mathrm{mg} \mathrm{kg}^{-1}$ soil. Root $\mathrm{Cd}$ concentrations were increased from 8.20 to 24.0 and from 6.10 to $17.40 \mathrm{mg} \mathrm{kg}^{-1}$ in C. erectus and E. camaldulensis, respectively with increasing the soil $\mathrm{Cd}$ concentration from the lower level $\left(5 \mathrm{mg} \mathrm{kg}^{-1}\right.$ soil) to the higher level $\left(15 \mathrm{mg} \mathrm{kg}^{-}\right.$ ${ }^{1}$ soil). 

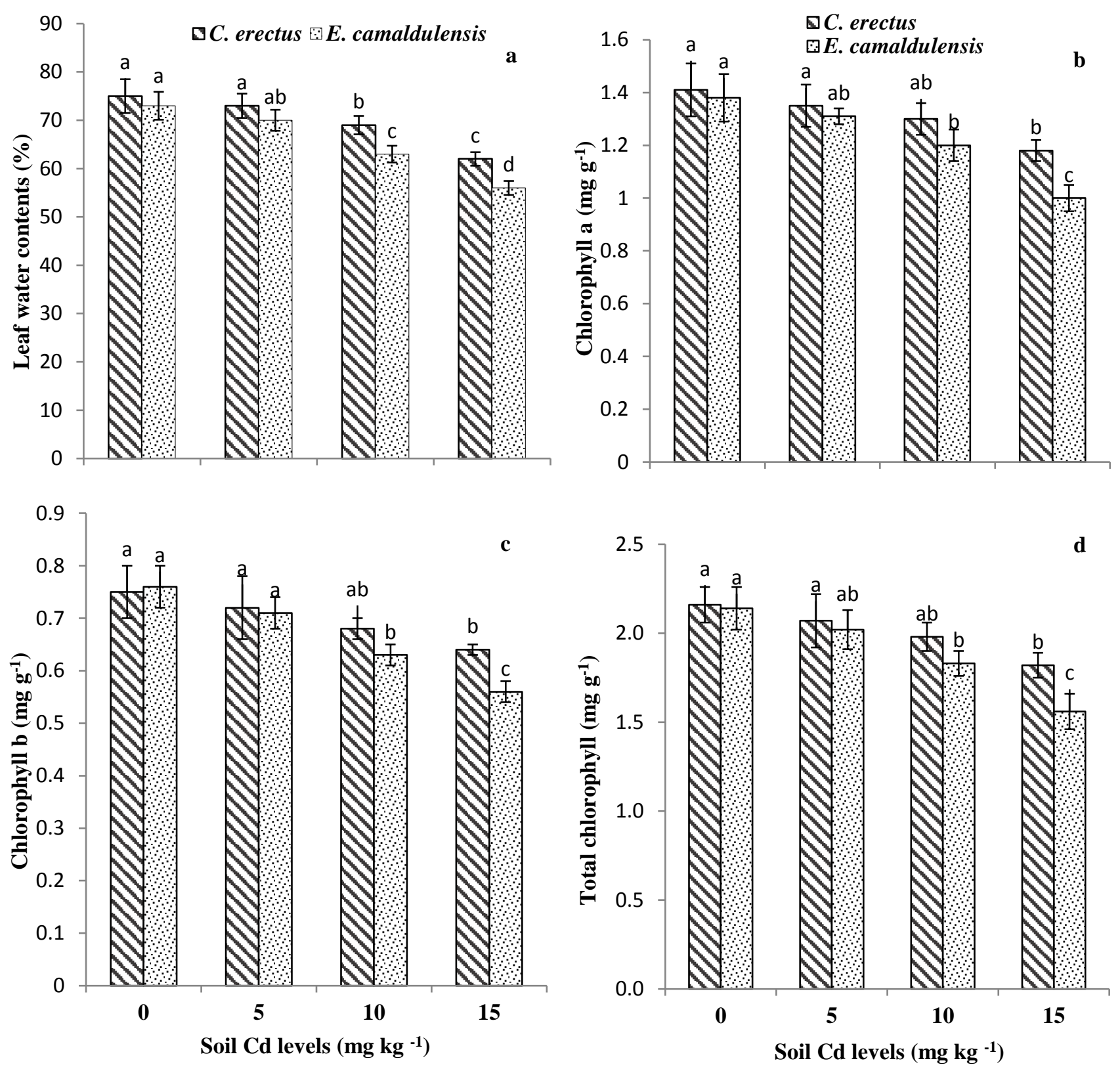

Figure 2. Effects of different soil Cd levels $\left(\mathrm{mg} \mathrm{kg}^{-1}\right)$ on leaf water contents (a) chlorophyll a (b) chlorophyll b (c) and total chlorophyll contents (d) of $\boldsymbol{C}$. erectus and $E$. camaldulensis. Values are the mean \pm standard error of three replicates.

Shoot and root Cd uptake (concentration * dry weight) also increased in both species with increasing the soil Cd levels (Fig. 4 a, b). Shoot Cd uptake was increased from 38.6 to 77.3 $\mu \mathrm{g} \mathrm{Cd} \mathrm{plant}{ }^{-1}$ in C. erectus and from 28.7 to $57.8 \mu \mathrm{g} \mathrm{Cd} \mathrm{plant}^{-}$ 1 in E. camaldulensis with increasing soil $\mathrm{Cd}$ concentration from 5 to $15 \mathrm{mg} \mathrm{kg}^{-1}$ soil. Root Cd uptake was increased from 44.3 to 110.4 in C. erectus and from 31.7 to $69.6 \mu \mathrm{g} \mathrm{Cd} \mathrm{plant}^{-}$ ${ }^{1}$ in E. camaldulensis as the soil Cd level was increased from the lower level ( $5 \mathrm{mg} \mathrm{kg}^{-1}$ soil) to the higher level $\left(15 \mathrm{mg} \mathrm{kg}^{-}\right.$
${ }^{1}$ soil).

Bioconcentration factor $(\mathrm{BCF})$ and translocation factor $(\boldsymbol{T F})$ : The values of BCF were greater than one for both the species for all the soil Cd levels (Table 2). The comparison of both species showed that $\mathrm{BCF}$ was higher for $C$. erectus than E. camaldulensis. Data regarding root to shoot $\mathrm{Cd}$ translocation showed that the TF was less than one for both species for all the soil Cd levels (Table 2). Comparison of both 
tree species indicated that $\mathrm{TF}$ was higher in E. camaldulensis than C. erectus.

Table 2. Effects of different soil Cd levels $\left(\mathrm{mg} \mathrm{kg}^{-1}\right)$ on translocation factor (TF) and bioconcentration factor (BCF) of $C$. erectus and $E$. camaldulensis

\begin{tabular}{lcccc}
\hline \multirow{2}{*}{$\begin{array}{l}\text { Soil Cd } \\
\text { levels }\end{array}$} & \multicolumn{2}{c}{ Translocation factor } & \multicolumn{2}{c}{ Bioconcentration factor } \\
\cline { 2 - 5 } & C. erectus & $\begin{array}{c}\boldsymbol{E} \text {. } \\
\text { camaldulensis }\end{array}$ & C. erectus & $\begin{array}{c}\boldsymbol{E} \text {. } \\
\text { camaldulensis }\end{array}$ \\
\hline $\mathbf{0}$ & $0.42 \pm 0.05$ & $0.33 \pm 0.04$ & $2.37 \pm 0.11$ & $2.67 \pm 0.10$ \\
$\mathbf{5}$ & $0.51 \pm 0.06$ & $0.54 \pm 0.08$ & $1.64 \pm 0.10$ & $1.22 \pm 0.11$ \\
$\mathbf{1 0}$ & $0.48 \pm 0.04$ & $0.56 \pm 0.06$ & $1.56 \pm 0.15$ & $1.10 \pm 0.10$ \\
$\mathbf{1 5}$ & $0.40 \pm 0.02$ & $0.48 \pm 0.08$ & $1.60 \pm 0.18$ & $1.16 \pm 0.12$ \\
\hline
\end{tabular}
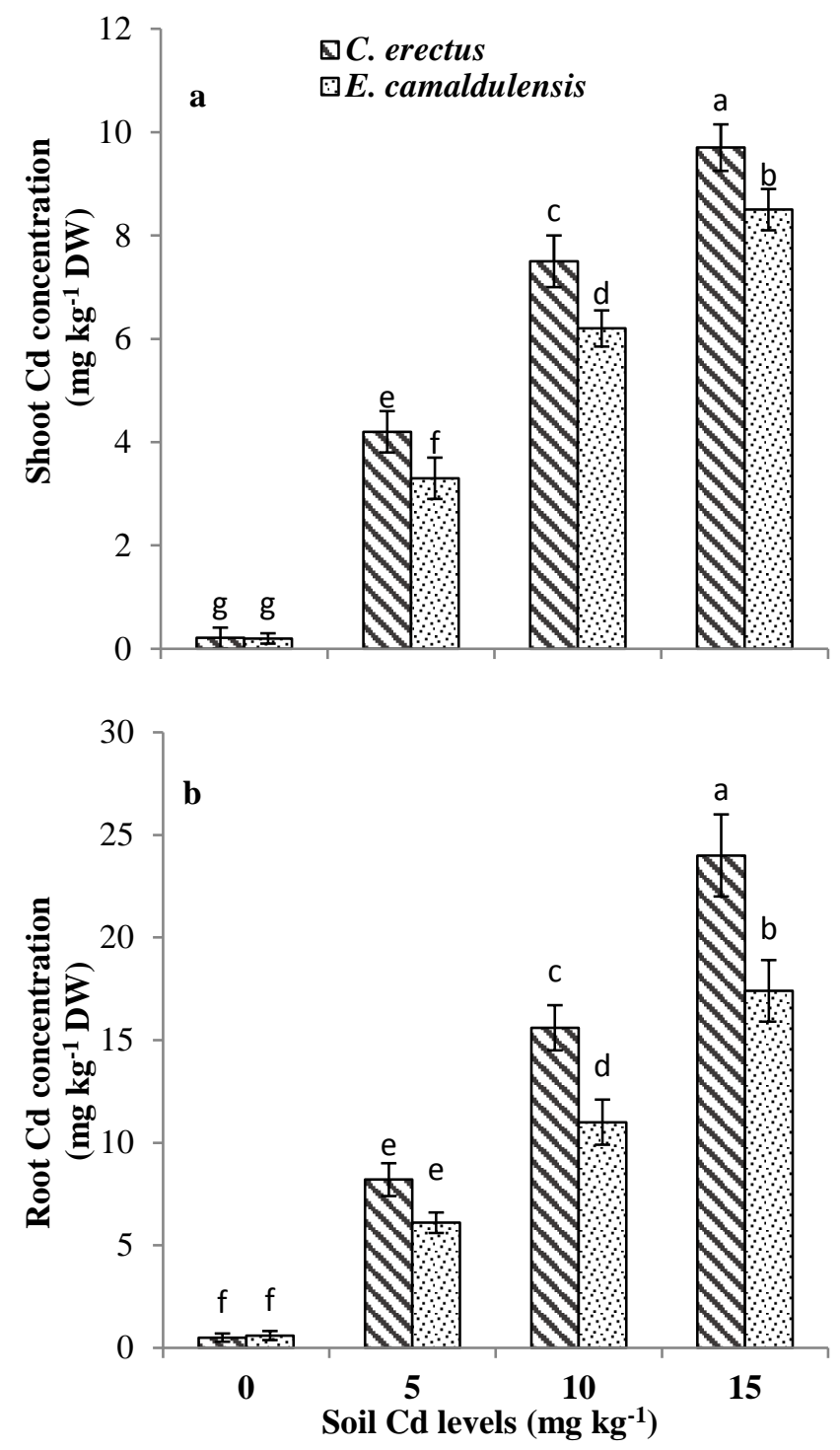

Figure 3. Effects of different soil Cd levels $\left(\mathrm{mg} \mathrm{kg}^{-1}\right)$ on shoot (a) and root (b) $C d$ concentrations of $C$. erectus and $E$. camaldulensis. Values are the mean \pm standard error of three replicates.
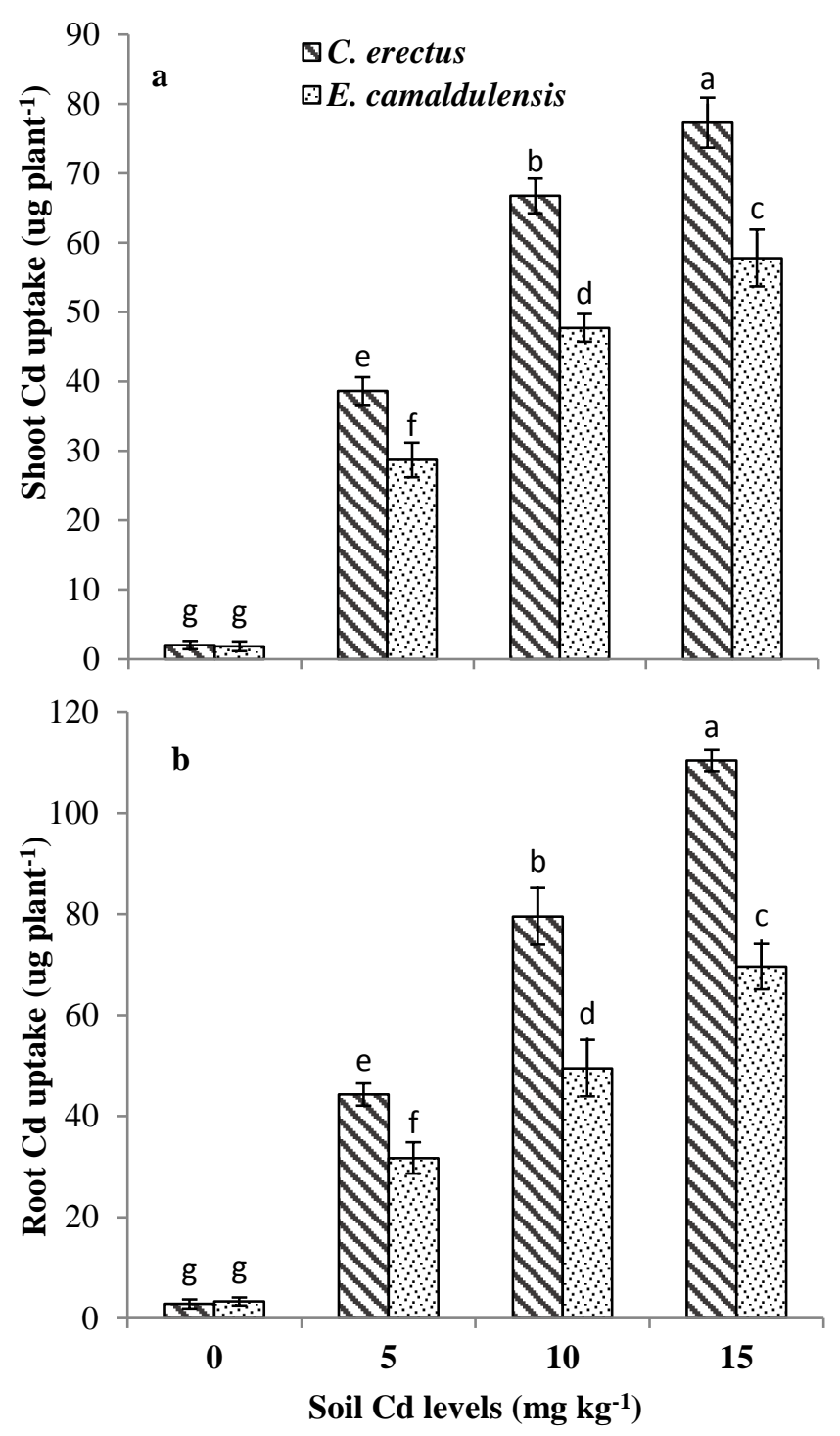

Figure 4. Effects of different soil Cd levels $\left(\mathrm{mg} \mathrm{kg}^{-1}\right)$ on shoot (a) and root (b) Cd uptake of C. erectus and $E$. camaldulensis. Values are the mean \pm standard error of three replicates.

\section{DISCUSSION}

The results of the present study demonstrated that root and shoot growth of both tree species was differently affected by various soil $\mathrm{Cd}$ levels. Root and shoot growth of $E$. camaldulensis was reduced at the lower $\left(10 \mathrm{mg} \mathrm{kg}^{-1}\right.$ soil) soil $\mathrm{Cd}$ level. On the other hand, only the highest soil Cd level (15 $\mathrm{mg} \mathrm{kg}{ }^{-1}$ soil) caused a noticeable reduction in root growth of C. erectus as compared to control treatment. Many previous studies (Wu et al., 2010; Bauddh and Singh, 2012; Abbasi et al., 2015; Hammami et al., 2016) reported reduction in growth of various plant species in response to $\mathrm{Cd}$ stress. Contrary to these findings, Manousaki and Kalogerakis 
(2009) did not observe any significant effect of Cd on the root growth of Atriplex halimus and declared it as a Cd tolerant species. Qados (2015) observed a significant reduction in shoot dry biomass of three tree species at higher soil $\mathrm{Cd}$ level (100 $\mathrm{mg} \mathrm{kg}^{-1}$ soil) as compared to the Cd levels used in the present study. Such differences might be due to different growth conditions (both the soil and climate), and the tree species under consideration.

Growth inhibition, an index of tolerance determination, is a commonly observed response in non-hyper accumulating plants in response to Cd stress (Wu et al., 2010; Pietrini et al., 2015), and is related to $\mathrm{Cd}$ induced water and nutrient imbalance, oxidative stress, changes in enzymatic activities, injuries to the photosynthetic apparatus, and disturbance to many other metabolic activities (Gallego et al., 2012; Andresen and Kupper, 2013; Shabir et al., 2017).

Leaf water contents and chlorophyll contents are regarded as important components of metal tolerance of plants, and both of these attributes are generally decreased when plants are exposed to Cd contamination (Liu et al., 2016; Pietrini et al., 2015). We found that $C$. erectus maintained relatively higher leaf water contents than E. camaldulensis which is an indication of its higher tolerance than its counterpart. Similarly, Manousaki and Kalogerakis (2009) observed that leaf water contents of Atriplex halimus were not much affected by various soil $\mathrm{Cd}$ treatments showing its tolerance against Cd stress.

Cadmium is not involved in any known function in plants (Wu et al., 2010). It is easily taken up by plant roots and translocated to shoots where it affects many crucial metabolic activities in different cellular compartments (Prasad, 2004; Pietrini et al., 2015). Due to detrimental effects of $\mathrm{Cd}$ to chloroplasts, the pigment contents are reduced (Mobin and Khan, 2007; Pietrini et al., 2010b). We observed that chlorophyll contents (chl a, chl b and total chl) were decreased in both the species, however, the reduction was more in the case of E. camaldulensis than $C$. erectus indicating relatively higher tolerance of the later species against Cd stress. Our results are in accordance with the findings of Pietrini et al. (2015), who observed that chlorophyll contents of two eucalyptus clones (Viglio and Velino) were reduced when the plants were grown in $\mathrm{Cd}$ contaminated water. The clone Velino was regarded as more tolerant than Viglio due to relatively less reduction in its chlorophyll contents.

Shoot and root $\mathrm{Cd}$ concentrations and uptake were increased in both the species with increasing Cd levels in the soil. Physicochemical characteristics of the soil (texture, $\mathrm{pH}$, lime contents, organic matter, salinity, form and amount of metal, presence of other metals), agro-climatic conditions of the experimental site, and the plant species have great influence on the bioavailability and uptake of $\mathrm{Cd}$ from the soil (Naidu et al., 2003; Bauddh and Singh, 2012; Shahid et al., 2017; Shabir et al., 2017). In our study, about $75 \%$ of the total $\mathrm{Cd}$ added to the soil was available for plant uptake mainly due to sandy loam texture and very low organic matter content of the soil. We found that root $\mathrm{Cd}$ concentration and uptake were much higher than shoot $\mathrm{Cd}$ concentration and uptake in both the species, and $C$. erectus showed more $\mathrm{Cd}$ concentration in both parts than E. camadulensis.

Such preferential accumulation of $\mathrm{Cd}$ in the roots of various eucalyptus species has also been reported by other researchers (Bauddh and Singh, 2012; Gomes et al., 2012; Pietrini et al., 2015). The mechanisms contributing to $\mathrm{Cd}$ sequestration and immobilization in roots include chelation of $\mathrm{Cd}$ by thiolcontaining peptides such as metallothioneins and phytochelatins, Cd compartmentalization in root vacuoles, and adsorption to the root cell walls (Nocito et al., 2011; Fine et al., 2013). It has been reported that $\mathrm{Cd}$ adsorption to roots mainly contributes to $\mathrm{Cd}$ binding in roots (Meighan et al., 2011). In our experiment, the contribution of adsorption to root uptake was eliminated by washing the roots with acid prior to drying. It is important to note that, although $\mathrm{Cd}$ concentration achieved in the roots of $C$. erectus was not much higher yet, due to its fast growth and high root biomass production potential, considerable quantity of $\mathrm{Cd}$ can be stabilized by growing this species on Cd contaminated soils. In the present study, BCF was greater than 1.0 for both tree species (Table 2). Michałowski and Gołas (2001) described a four-degree scale for accumulation of metals in plants. According to this scale, BCF less than 0.01, indicates no accumulation, 0.01-0.1 indicates low bioaccumulation, 0.11.0 corresponds to medium bioaccumulation and $>1.0$ represents a high bioaccumulation. Similarly, according to Negrete et al. (2015) and Melgar et al. (2009), a BCF value greater than one corresponds to metal accumulating behavior of the plants.

Based on the BCF values obtained in the present study, both tree species showed great potential for $\mathrm{Cd}$ accumulation in roots. On the other hand, TF was less than one for both tree species (Table 2), showing less transfer of $\mathrm{Cd}$ from roots to shoots. The plant should have BCF and TF greater than one for phytoextraction of metals. The higher BCF and lower TF obtained for both the species indicate their suitability to be used for phytostabilization of $\mathrm{Cd}$ in contaminated soils as reported by Tu et al. (2003), Fine et al. (2013) and MarrugoNegrete et al. (2015). However, due to relatively greater accumulation of $\mathrm{Cd}$ in roots and its less transfer to shoots in the case of $C$. erectus indicates that this trees species is more suitable than E. camadulensis for phytostabilization of $\mathrm{Cd}$ in contaminated soils.

Conclusions: The results of the present study suggest that the effects of $\mathrm{Cd}$ on growth and physiological attributes were less pronounced in $C$. erectus than E. camadulensis. Both tree species accumulated higher levels of $\mathrm{Cd}$ in roots which was indicted by their lower TF values. Less transfer of $\mathrm{Cd}$ from root to shoot indicated the phytostabilization behavior of both the species. Due to relatively higher Cd tolerance, and greater 
capacity to retain higher concentration of $\mathrm{Cd}$ in roots, $C$. erectus is a better choice than E. camadulensis for phytostabilzation of $\mathrm{Cd}$ contaminated soils.

Acknowledgements: The authors gratefully acknowledge the Higher Education Commission of Pakistan for providing financial support for this research. We are equally indebted to COMSATS University Islamabad for providing laboratory facilities and some technical assistance during the research work.

Conflict of Interest: The authors have no financial or commercial conflicts of interest for this particular study.

\section{REFERENCES}

Shabir, R., G. Abbas, M. Saqib, M. Shahid, G.M. Shah, M. Akram, N.K. Niazi, M.A. Naeem, M. Hussain and F. Ashraf. 2017. Cadmium tolerance and phytoremediation potential of acacia (Acacia nilotica L.) under salinity stress. Int. J. Phytorem. https://doi.org/10.1080/ 15226514. 2017.1413339.

Abbas, G., M. Saqib, J. Akhtar, G. Murtaza, M. Shahid and A. Hussain. 2016. Relationship between rhizosphere acidification and phytoremediation in two acacia species. J. Soils Sediments 16:1392-1399.

Abbasi, G.H., J. Akhtar, M.A. Haq, W. Malik, S. Ali, Z. Chen and G. Zhang. 2015. Morpho physiological and micrographic characterization of maize hybrids under $\mathrm{NaCl}$ and $\mathrm{Cd}$ stress. Plant Growth Regul. 75:115-122.

Ali, H., E. Khan and M.A. Sajad. 2013. Phytoremediation of heavy metals-concepts and applications. Chemosphere 91:869-881.

Andresen, E. and H. Kupper. 2013. Cadmium toxicity in plants. In: A. Sigel, H. Sigel and R.K.O. Sigel (eds.), Cadmium: From Toxicity to Essentiality. Springer, Netherlands. pp. 395-413.

AOAC 1990. AOAC official methods of analysis. 15 ${ }^{\text {th }}$ Ed. Association of Official Analytical Chemists, Arlington, Virginia.

Bauddh, K. and R.P. Singh. 2012. Cadmium tolerance and its phytoremediation by two oil yielding plants Ricinus communis (L.) and Brassica juncea (L.) from the contaminated soil. Int. J. Phytorem.14:772-785.

Bhargava, A., F.F. Carmona and M. Bhargava. 2012. Approaches for enhanced phytoextraction of heavy metals. J. Environ. Manag. 105:103-120.

Bouyoucos, G.J. 1962. Hydrometer method improved for making particle size analysis. J. Agron. 53:464-465.

Fine, P., P.H. Rathod, A. Beriozkin and U. Mingelgrin. 2013. Uptake of cadmium by hydroponically grown, mature Eucalyptus camaldulensis saplings and the effect of organic ligands. Int. J. Phytorem. 15(6):585-601.
Gallego, S.M., L.B. Pena, R.A. Barcia, C.E. Azpilicueta, M.F. Lannone, E.P. Rosales, M.S. Zawoznik, M.D. Groppa and M.P. Benavides. 2012. Unravelling cadmium toxicity and tolerance in plants: insight into regulatory mechanisms. Environ. Exp. Bot. 83:33-46.

Ghosh, A., M.G. Dastidar and T.R. Sreekrishnan. 2016. Recent advances in bioremediation of heavy metals and metal complex dyes. J. Environ. Eng. 142:1-14.

Ghosh, M. and S.P. Singh. 2005. A comparative study of cadmium phytoremediation by accumulator and weed species. Environ. Pollut. 33:365-371.

Gomes, M.P., T.C.L.L.S.M. Marques, M.M.L.C. Carneiro and A.M. Soares. 2012. Anatomical characteristics and nutrient uptake and distribution associated with the $\mathrm{Cd}$ phytoremediation capacity of Eucalyptus camaldulenses Dehnh. J. Soil Sci. Plant Nut. 12(3):481-495.

Hammami, H., M. Parsa, M.H.R. Mohassel, S. Rahimi and S. Mijani. 2016. Weeds ability to phytoremediate cadmiumcontaminated soil. Int. J. Phytorem. 18:48-53.

He, S., Z. He, X. Yang, P.J. Stoffella and V.C. Baligar. 2015. Soil biogeochemistry, plant physiology, and phytoremediation of cadmium-contaminated soils. Adv. Agron. 134:134-225.

Hussain, S., M. Akram, G. Abbas, B. Murtaza, M. Shahid, N.S. Shah, I. Bibi and N.K. Niazi. 2017. Arsenic tolerance and phytoremediation potential of Conocarpus erectus L. and Populus deltoides L. Inter J. Phytorem. 19(11):985-991.

Jackson, M.L. 1962. Soil chemical analysis. Prentice Hall Inc., Englewood Cliffs, NJ.

Kabata-Pendias, A. and S. Dudka. 1990. Evaluating baseline data for cadmium in soils and plants in Poland. In: $\mathrm{H}$. Lieth and B. Markert (eds.), Element concentration cadasters in ecosystems. VCH Publisher, Weinheim, Germany. pp. 265-280.

Kausar, A., M.Y. Ashraf, I. Ali, M. Niaz and Q. Abbas. 2012. Evaluation of sorghum varieties/lines for salt tolerance using physiological indices as screening tool. Pak. J. Bot. 44(1):47-52.

Liu, X., C. Lou, L. Xu and L. Sun. 2012. Distribution and bioavailability of cadmium in ornithogenic coral-sand sediments of the Xisha archipelago, South China Sea. Environ. Pollut. 168:151-160.

Liu, Z., Y. Ding, F. Wang, Y. Ye and C. Zhu. 2016. Role of salicylic acid in resistance to cadmium stress in plants. Plant Cell Rep. 35:719-731.

Lichtenthaler, H.K. 1987. Chlorophylls and carotenoids: pigments of photosynthetic bio membranes. Methods Enzymol. 148:350-382.

Manousaki, E. and N. Kalogerakis. 2009. Phytoextraction of $\mathrm{Pb}$ and $\mathrm{Cd}$ by the Mediterranean saltbush (Atriplex halimus L.): metal uptake in relation to salinity. Environ. Sci. Pollut. Res. 16:844-854. 
Manousaki, E., F. Kokkali and N. Kalogerakis. 2009. Influence of salinity on lead and cadmium accumulation by the salt cedar (Tamarix smyrnensis Bunge). J Chem. Technol. Biotechnol. 84:877-883.

Marrugo-Negrete, J., J. Durango-Hernández, J. PinedoHernández, J. Olivero-Verbel and S. Díez. 2015. Phytoremediation of mercury-contaminated soils by Jatropha curcas. Chemosphere 127:58-63.

Meighan, M.M., T. Fenus, E. Karey and J. MacNeil. 2011. The impact of EDTA on the rate of accumulation and root/shoot partitioning of cadmium in mature dwarf sunflowers. Chemosphere 83:1539-1545.

Melgar, M.J., J. Alonso and M.A. García. 2009. Mercury in edible mushrooms and underlying soil: bioconcentration factors and toxicological risk. Sci. Total Environ. 407:5328-5334.

Michałowski, M., and J. Gołas. 2001. The contents of selected heavy metals of willow organs as an indicator of their use in sewage sludge utilization. Workbooks of the Basic Problems of Agri. Sci. 477:411-419.

Nazar, R., N. Iqbal, A. Masood, S.R. Syeed, M.I. Khan and N. Khan. 2012. Cadmium toxicity in plants and role of mineral nutrients in its alleviation. Am. J. Plant Sci. 3:1476-1489.

Niazi NK, Singh B, Shah P. 2011. Arsenic speciation and phytoavailability in contaminated soils using a sequential extraction procedure and XANES spectroscopy. Environ. Sci. Technol. 45:7135-7142.

Niazi, N.K., I. Bibi, A. Fatimah, M. Shahid, M.T. Javed, H. Wang, Y.S. Ok, S. Bashir, B. Murtaza, Z.A. Saqib and M.B. Shakoor. 2017. Phosphate-assisted phytoremediation of arsenic by Brassica napus and Brassica juncea: morphological and physiological response. Inter. J. Phytorem. 19:670-678.
Nocito, F.F., C. Lancilli, B. Dendena, G. Lucchini and G.A. Sacchi. 2011. Cadmium retention in rice roots is influenced by cadmium availability, chelation and translocation. Plant Cell Environ. 43:994-1008.

Pietrini, F., V. Iori, D. Bianconi, G. Mughini, A. Massacci and M. Zacchini. 2015. Assessment of physiological and biochemical responses, metal tolerance and accumulation in two eucalypt hybrid clones for phytoremediation of cadmium-contaminated waters. J. Environ. Manag. 162:221-231.

Pulford, I.D. and C. Watson. 2003. Phytoremediation of heavy metal contaminated land by trees. Environ. Int. 29:529-540.

Qados, A.M.S.A. 2015. Phytoremediation of $\mathrm{Pb}$ and $\mathrm{Cd}$ by native tree species grown in the Kingdom of Saudi Arabia. Int. J. Sci. Res. Tech. 3:22-34.

Richard, L.A. 1954. Diagnosis and improvement of saline and alkali soils. USDA Handbook 60, Washington, DC.

Steel, R.G.D., J.H. Torrie and D. Dickey. 1997. Principles and Procedures of Statistics: A Biometrical Approach, $3^{\text {rd }}$ Ed. McGraw Hill Book Co. Inc., New York, USA.

Wang, A., M. Wang, Q. Liao and X. He. 2016. Characterization of $\mathrm{Cd}$ translocation and accumulation in 19 maize cultivars grown on Cd-contaminated soil: implication of maize cultivar selection for minimal risk to human health and for phytoremediation. Environ. Sci. Pollut. Res. 23:5410-5419.

Wu, F., W. Yang, J. Zhang and L. Zhou. 2010. Cadmium accumulation and growth responses of a poplar (Populus deltoids $\times$ Populus nigra) in cadmium contaminated purple soil and alluvial soil. J. Hazard. Mater. 177:268273. 